\title{
Transformations of the global society: reading suggestions
}

\author{
PhD. Isabella francisca freitas Gouveia de Vasconcelos ${ }^{1}$ \\ PhD. HÉLIo ARThur Reis IRIgaraY ${ }^{1}$ \\ 1Fundação Getulio Vargas / Escola Brasileira de Administração Pública e de EMpresas, Rio de Janeiro - RJ, Brazil
}

This issue presents articles and theoretical essays based on the works of sociologists and philosophers who have greatly influenced the development of organizational theories.

Alberto Guerreiro Ramos and Michel Foucault are among these scholars, inspiring the first and second articles of this issue, respectively. The third article is grounded on symbolic interactionism (Berger and Luckmann), and the fourth honors the contributions of the sociologist Pierre Bourdieu.

The other studies published in this issue address the application of organizational theories to public management.

The work of Alberto Guerreiro Ramos inspired many authors that were fundamental for the development of organizational studies in Brazil, such as Professor Fernando Cláudio Prestes Motta, who was titular Professor and Professor Emeritus of FGV EAESP (http://www.fernandoprestesmotta.com.br/?pg=home). Another important author in this context is Professor Dr. Fernando Tenório, from FGV EBAPE, who in his period as editor of Cadernos EBAPE.BR, published many special issues offering space for researchers influenced by the work of Guerreiro Ramos. Professor Tenório encouraged the publication of special issues dedicated to philosophy and sociology and to the influence of them on the theory of organizations, as well as articles based on critical works such as those of Habermas.

In recent studies on global warming and policies to preserve the environment and promote social justice, many scientists from areas such as biology, astronomy, and geography propose other perspectives for the communication between nations, scientists, and politicians. In view of the interest of humanity, communication should overcome the immediate political interests and be grounded on facts and scientific data considering the defense of humanist interests, as proposed by Habermas' theory of communicative action. Therefore, from actions to defend the planet's ozone layer, such as the Montreal Protocol, until the recent Paris Agreement that brought together more than 170 nations, communication in these cases is democratic and humanistic, considering humanity's common interests.

Based on the themes presented in this issue, particularly regarding the field of economics, we would like to suggest to our readers the book 'Economics for the Common Good' by Jean Tirole (2017), Nobel Prize for Economics in 2014. Tirole addresses digital economy and other topics such as the relation of economy and environmental protection, and the book presents the contributions of the author in scientific but accessible language.

Another book we would like to suggest is the work, available in Portuguese, "Tem razão a administração? Ensaios de teoria organizacional e gestão social," by Professor Tenório. The book helps to understand the convergences of the work of the sociologists mentioned at the beginning of this editorial, especially Habermas.

The convergences between our thoughts as Cadernos EBAPE.BR's editors and the thoughts expressed here, lead us to recommend the site of the research group Transformare (www.transformare.adm.br).

Article 1, "The "blind spots" of organizational theories according to Guerreiro Ramos," by Susana Iglesias Webering, is based on two books by Alberto Guerreiro Ramos, Administração e contexto brasileiro (Administration and Brazilian context) and $A$ nova ciência das oganizações (The new science of organizations), written by Guerreiro Ramos. The study presents the main aspects of the organizational theories analyzed by Ramos. 
Article 2, "Notions of subject and power in Foucaultian readings and their influence in organization and people management studies," by Magno Geraldo de Aquino, reflects on the notion of subject and power characterized by Michel Foucault (19261984), considering the three intellectual phases and possibilities of the subject, as portrayed in studies on organizations and people management. The research assumes that the ways in which Foucault characterized the subject in intellectual phases reflects the ways the organization manages the individual. In addition, this work highlights the potential of the Foucaultian approach regarding the analysis of subjects and the relations of power in the organizations.

Article 3, "The semiotics of tacit knowledge sharing: a study from the perspective of symbolic interactionism," by Lilian Aparecida Pasquini Miguel and Silvio Popadiuk, proposes an integrated theoretical model, combining Polany and Peirce constructs - tacit knowledge and semiotics, respectively - under the symbolic interactionist perspective. It aims to understand how signs are manifested as mediators in the tacit knowledge sharing process among members of a cooperative organization.

Article 4, "Between consensus and dissension: legitimation strategies in the bureaucratic field of State in action in favelas," by Vanessa Brulon and Alketa Peci, analyzes the legitimation strategies used by field agents of the state in action in favelas, as a way to bring light to the disputes in the field. Based on Bourdieu's theoretical perspective and in ethnographic field research in two favelas of Rio de Janeiro, the study conducts a rhetorical analysis on the discourse of the field agents, to access their legitimation strategies.

Article 5, "Dual career couples and their inclinations regarding work and family: the Brazilian scenario," by Heliani Berlato, Thais Fernandes, and Daielly Melina Nassif Mantovani, explores the database of the National Household Sample Survey (PNAD) produced by the IBGE (Brazilian Institute of Geography and Statistics) in order to investigate how couples from a dual-career perspective approach the demands of home and work.

Article 6, "Territorial governance and social innovation in regional development processes in mining territories: a theoretic model under construction," by Paula Pessoa de Castro Gentil, Liliane de Oliveira Guimarães, Denise de Castro Pereira, Alexandre Magno Diniz, and Ivan Beck Ckagnazaroff, shows that there are serious contradictions between the proclaimed economic benefits obtained by localities where the mineral extraction industry historically operates, and the results recorded in research work. Studies have pointed out serious problems and negative consequences from the mineral extraction industry's questionable form of management and relationship with the local environment. These practices have increased the socioeconomic and environmental vulnerability of the territories, both in local and regional dimensions.

Article 7, "Resources for education and results achieved in the Ideb of a Brazilian capital city," by Manoel Carlos de Oliveira Júnior, Américo Matsuo Minori and Marcelo Souza Frota, analyzes the relationship between investments on education and indicators that monitor the development of education quality, particularly the Index of Development of Basic Education (IDEB). The research carried out a quantitative and bibliographical and documentary investigation.

Article 8, "Beyond management: the process of managing at a Public School of Elementary Education in Brazil," by Lucas Poubel and Gelson Silva Junquilho, aims to understand the so-called managing process in a public elementary school as a relational and emergent process, beyond the idea of management. Managing as a process in Brazilian public schools is a phenomenon with peculiar characteristics, since it involves multiple actors of a school community. Everyday practices, conflicts, uncertainties, negotiations, and diverse interests constantly arise in school life.

Article 9, "Coordination of advocacy coalitions using cognitive maps," by Cristiano Santos Lúcio de Melo and Diego Mota Vieira, contributes to the analysis of advocacy coalitions in processes of formulation or change of public policies, combining public policy analysis and operational research models.

Article 10, "Class stratification and social mobility in the transition from school to work of Brazilian youths: reflections and research agenda," by Bibiana Volkmer Martins, Camila Scherdien and Sidinei Rocha-de-Oliveira, points at the importance of studies on the insertion in the labor market in Brazil. The authors carried out a reflection on the transition from school to work, observing the increase in enrolment for higher education and the organizational discourse about the lack of skilled labor force in the country. However, many of the existing studies refer to empirical research, without considering some particularities of this transition process, such as socioeconomic specificities and the recent increase in access to higher education in Brazil. 
Article 11, “A study of relations between gender and careers anchors," by Adriane Vieira, Plínio Rafael Reis Monteiro, Alexandre de Pádua Carrieri, Vanessa de Almeida Guerra and Luiz Carlos Brant, analyzes the relationship between gender and career anchors of undergraduate students, using the survey method. The sample totaled 251 Engineering students and 251 Health Care students. To collect the data, we used questionnaires containing the Inventory Career Guidance of Schein (1990). The analysis techniques used were descriptive statistics and exploratory factor analysis. The results show that, in the Engineering area, female respondents valued more the lifestyle and safety anchors, whose attributes are socially associated with gender.

Article 12, "A 'bid aesthetic' of an 'ordinary heroin': the reorganizing of an artesian resistance practices," by Rosa Cristina Lima Ribeiro, Ana Silvia Rocha Ipiranga, Fabíola Faria Tostes de Oliveira and Allan Daniel Dias, adopts a feminist perspective in the analysis of the infra-political resistance practices, a perspective that is needed in organization studies. The study aims to understand the organization of everyday practices that involves "bid aesthetics" and resistance tactics and strategies, of an infra-political character, observing the art of an artisan and actions from a women's network which she is a member of. The research methodology used the qualitative approach, focusing on case study, supported by direct observation, documentary research, field diary, and in-depth interviews.

Article 13, "Tax morals and the Brazilian citizen: an empirical study," by Antonio Lopo Martinez and Marcelo Lopes Bello Coelho, analyzes the tax morals of the Brazilian citizen, aiming to measure its level, as well as if there is a difference of the tax morals in the sociodemographic characteristics. Tax morale is an important determinant of compliance with tax legislation, so measuring it and evaluate each aspect that determines it allows to strategize and ensure better fiscal conformity. The research period was between May and August 2017, with 679 participants.

Article 14, "Strategic circumvention of regulations: the judicialization of the Brazilian private health system," by Arnaldo L. Ryngelblum, Paulo C. Duarte de Oliveira, Renato Telles, and Mayla C. Costa, advances the understanding of the successive circumvention of regulations by organizations, to determine whether it is possible to characterize them as purposeful actions, while the institutional literature analyzes decoupling and circumvention as sporadic activities. It analyzes the responses adopted by health plan companies to favor their interests, responses that often fail to comply with the rules of the institutional context, and which boosted the phenomenon known as 'judicialization'. The study analyzed 158 lawsuits collected from the electronic archives of the Court of Justice of São Paulo, where beneficiaries sue health plan companies because of treatment coverage denial.

Article 15, "Dynamic networks in early international agribusiness," by Christiam Mendez Lazarte, aims to understand the benefits of networks, based on their origin, for the process of companies' accelerated internationalization. The study adopts as a reference the emergence of Born Global enterprises, International New Ventures (INV), and the Networking approach. An inductive and interpretative method was applied, using in-depth interviews, triangulated with public documents about the studied companies. The research analyzed two companies oriented to international markets since their establishment. The interviews' transcripts were analyzed using matrices elaborated throughout the study, relating relevant factors both for this type of enterprises and for the typologies of networks.

We wish you a pleasant read,

PhD. Isabella F. Freitas Gouveia de Vasconcelos

PHD. HÉLIO ARTHUR REIS IRIGARAY

EDITORS-IN-CHIEF 


\section{REFERENCES}

SAGAN, C. Billions and Billions (Pocket). Tradução: Rosaura Eichenberg, São Paulo: Companhia das Letras. 288p.

TENÓRIO, F. G. Tem Razão A Administração? Ensaios de teoria organizacional e gestão social. 4. ed. Ijuí: Unijuí, 2016.
TIROLE, J. Economics for the Common Good. Princeton: Princeton University Press, 2017.

PhD. Isabella Francisca Freitas Gouveia de Vasconcelos

ORCID: https://orcid.org/0000-0001-9109-0475

Doctorat es Sciences de Gestion / HEC - Ecole des Hautes Etudes Commerciales, France (2000); PhD in Human Resource Administration from FGV EAESP (1997), Brazil; Post-Doctorate from Rutgers, The New Jersey State University, USA; Adjunct Professor at FGV EBAPE, Brazil; Researcher at CNAMConservatoire National D’Arts et Metiers, France. E-mail: isabella.vasconcelos@fgv.br

PhD. Hélio Arthur Reis Irigaray

ORCID: https://orcid.org/0000-0001-9580-7859

PhD in Business Administration from FGV EAESP; Masters in Business Administration from PUC-Rio and Bachelor Degree in Economics from the University of Northern lowa, USA. Assistant Professor at FGV EBAPE and at the Corporate International Masters (CIM) program of the Georgetown University, Washington, USA. Leader researcher on the theme Diversity and Labor Relations, in the area of Work Management of the National Association of Graduate Studies and Research in Administration (ANPAD). E-mail: helio.irigaray@fgv.br 